\title{
Revision of the planktonic foraminiferal biostratigraphy of the Voirons Flysch (Chablais Prealps, Haute-Savoie, France)
}

\author{
Jérémy Ragusa ${ }^{1}\left(\mathbb{0} \cdot\right.$ Lina Maria Ospina-Ostios $^{2} \cdot$ Silvia Spezzaferri $^{3} \cdot$ Pascal Kindler $^{1}$
}

\begin{abstract}
The ages obtained from planktonic foraminiferal assemblages retrieved from two exposures in the Gurnigel Flysch and from the re-examination of similar material gathered by previous researchers from the Voirons Flysch reveal only minor discrepancies with previous studies based on nannofossil biostratigraphy. In contrast, major divergences between this work and previous studies on the Voirons Flysch also based on planktonic foraminifera have been identified. They are generally related to distinct approaches in species classification and the use of different zonal schemes. Based on our data, the age of the Voirons Flysch extends from the Early Eocene (planktonic foraminiferal zone P7) to the Middle Eocene (planktonic foraminiferal zone P12). Contrasting with claims made in earlier studies, no specimen of Late Eocene or Early Oligocene age has been observed in the revised material. However, we cannot exclude a younger age (possibly Late Eocene) for the upper portion of this flysch from which we did not revise any sample. Thus, more research and sampling are needed to resolve this question. The palaeogeographic origin of the Voirons-Wägital complex as well as the sedimentation history of these flyschs need now to be re-evaluated in light of this revised biostratigraphic data.
\end{abstract}

Keywords Biostratigraphy $\cdot$ Flysch $\cdot$ Palaeogene $\cdot$ Planktonic foraminifera · Valais domain · Voirons-Wägital complex

\section{Introduction}

The term "flysch" (e.g. Studer 1848; Wildi 1987; Homewood and Lateltin 1988) designates terrigenous sediments of Alpine basins that have been redeposited in the deep sea by gravity-flow processes during a period of convergence. Flysch deposits primarily consist of alternations of shales,

Electronic supplementary material

Jérémy Ragusa

jeremy.ragusa@hotmail.fr

1 Department of Earth Sciences, University of Geneva, Rue des Maraîchers 13, 1205 Geneva, Switzerland

2 Universidad del Valle, Escuela de Ingeniería Civil y Geomática, Cali, Colombia

3 Unit of Earth Sciences, Department of Geosciences, University of Fribourg, Chemin du Musée 6, 1700 Fribourg, Switzerland sandstones and conglomerates showing evidence of massflow transport (i.e. turbidites s.l., Mutti et al. 2009). They represent the last depositional stage in successive palaeogeographic domains before their subduction and subsequent accretion into a sedimentary accretionary prism (Kuenen and Carozzi 1953; Homewood and Lateltin 1988; Stampfli et al. 2002). Constraining the age of flysch units is thus critical for reconstructing the kinematics of orogenies (Stampfli et al. 2002; Stampfli and Hochard 2009; Handy et al. 2010).

Micro- and nannofossils are the most powerful tools for dating marine detrital sequences. This task is however greatly complicated due to the importance of reworking processes on the sea floor, which may incorporate material derived from older sediments in the flysch (e.g. Morel 1980; Mulder and Alexander 2001). The most appropriate dating technique consists in retrieving micro- and nannofossils from the pelagic beds interspersed in flysch successions (e.g. Ujetz 1996). Unfortunately, the preservation of hemipelagic layers is variable, and depends on the depositional environment. These layers are absent or rare in the amalgamated coarse-grained sandstones to conglomerates of channel settings, and can be confused with the 
fine-grained division of Bouma sequences (Te; Bouma 1962) in lobe settings (Mutti et al. 2003) commonly forming the bulk of flysch shales.

Initial attempts to date flysch deposits were based on larger benthic foraminifera (Pilloud 1936; Lombard 1940; Schaub 1951; Rigassi 1958; Cogulu 1961; Schaub et al. 1965). However, these organisms are mostly reworked from neighbouring carbonate platforms where they thrived during the Palaeogene (Scheibner and Speijer 2008). Calcareous nannofossils provided the first accurate biostratigraphic determinations in Alpine flyschs (Heckel 1968; Jan du Chêne et al. 1975; Van Stuijvenberg 1980). More recently, planktonic foraminifera biostratigraphy was also applied in the Voirons Flysch (Ujetz 1996; Frébourg 2006; Ospina-Ostios et al. 2013; Ospina-Ostios 2017).

The flyschs exposed in the Chablais and Swiss Prealps (Fig. 1) range in age from the Late Cretaceous to the Oligocene (Matter et al. 1980; Homewood and Caron 1982; Caron et al. 1989). As illustrated in Caron et al. (1989), the oldest flysch units are derived from the most internal palaeogeographic realms (e.g. the South-Penninic domain), and form the upper portion of the Prealpine nappes stack (e.g. the Gets nappe). By contrast, the youngest ones, known as the North Helvetic Flysch group (MenkveldGfeller et al., 2016), originate from more external domains (e.g. the inner portion of the North Alpine foreland basin), and occur at the base of the nappe sequence. Determining the palaeogeographic origin of flyschs is fairly easy when such a succession occurs in stratigraphic continuity with pre-flysch deposits, as in the Briançonnais domain (Médianes Flysch, Caron et al. 1980; Brèche Flysch, Dall'Agnolo 2000). However, in the Chablais and Swiss Prealps, several flysch slices and nappes are indeed isolated from their substrate and, consequently, their palaeogeographic attribution largely depends on their inferred age.

This is the case of the Voirons Flysch, which forms the westernmost part of the former Gurnigel nappe, now called the Voirons-Wägital complex. This complex has long been considered as related to the Ultrahelvetic domain due to its low structural position (Lombard 1940; Trümpy 1960; Hsü and Schlanger 1971). In the late twentieth century, it was attributed to the South-Penninic domain based on micropalaeontological data and because of its petrographic resemblance with the Sarine nappe (Upper Prealps; Caron 1976; Caron et al. 1980; Van Stuijvenberg and Jan du Chêne 1980; Caron et al. 1989; Gasinski et al. 1997). In the past two decades, several researchers (Ujetz 1996; Coppo, 1999; Frébourg 2006; Ospina-Ostios et al. 2013, OspinaOstios 2017) found planktonic foraminiferal assemblages indicating a Middle Eocene to Early Oligocene age in the Voirons Flysch, which precludes a South-Penninic origin for this unit. Consequently, and corroborating the ideas of

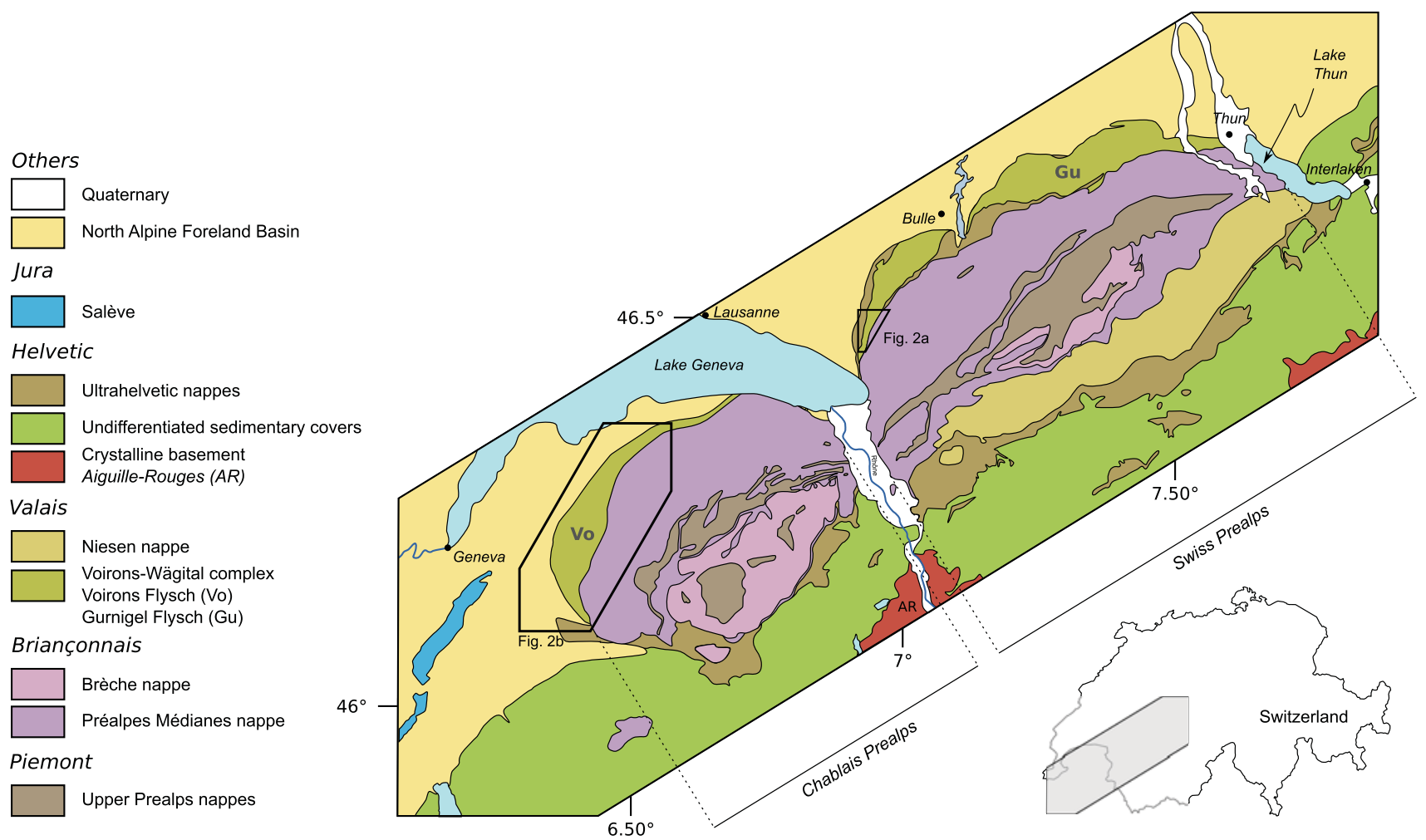

Fig. 1 Tectonic map of the Chablais and Swiss Prealps (SwissTopo 2008, modified) with the location of the western part of the Voirons-Wägital complex. The black boxes indicate the studied areas described in Fig. 2 


\section{(a) Gurnigel Flysch}

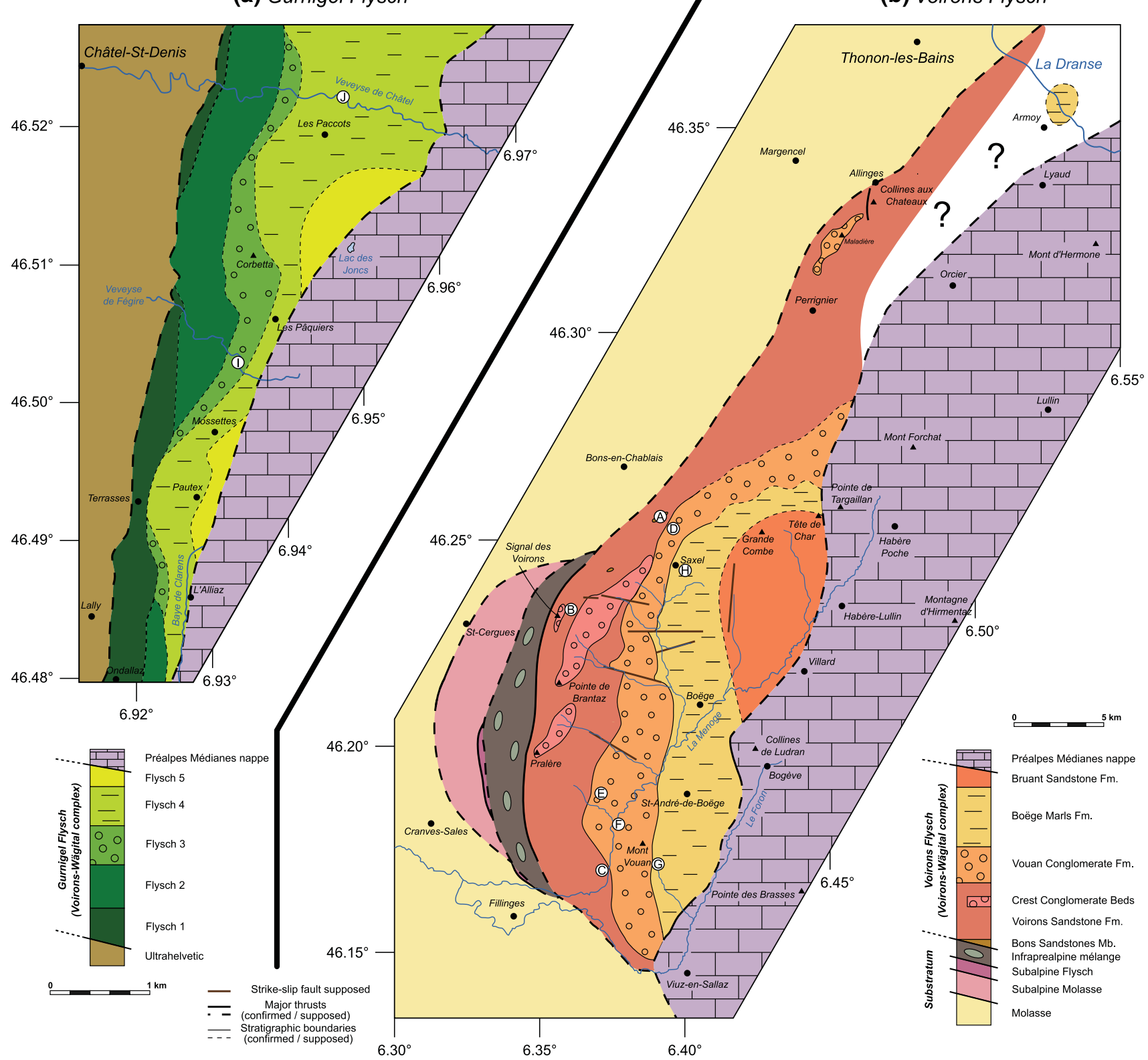

Fig. 2 Geologic map of the Gurnigel Flysch (Weidmann et al. 1976; Morel 1980, modified) and Voirons Flysch (Ragusa et al. 2017, modified) with the geographic location of the exposures where the studied or revised samples were collected (Table 1)

Schmid et al. (2005) as well as the conclusions of Trümpy (2006) for the easternmost part of the Voirons-Wägital complex (e.g. the Iberg Klippes), the Voirons Flysch was attributed to the Valais realm (Ospina-Ostios et al., 2013, Ragusa et al., 2017), which appears to agree better with its present-day low structural position but this is not the subject of the present paper.

The primary goal of this study was to apply planktonic foraminiferal biostratigraphy to exposures of the VoironsWägital complex in the western part of Switzerland to possibly confirm and substantiate the research made in the Voirons massif (Ujetz 1996; Coppo 1999; Frébourg 2006;
Ospina-Ostios et al. 2013, Ospina-Ostios 2017). However, our initial results from two outcrops in that area convinced us about the need of a thorough revision of the data from the Voirons Flysch, which is now the main aim of this paper.

\section{Geological setting}

The Voirons-Wägital complex, which includes the Voirons, the Gurnigel, the Schlieren and the Wägital Flyschs (Fig. 1), forms moderate-elevation, commonly forest- 
covered mountains (e.g. the Voirons, the Niremont) on the external edge of the Chablais and Swiss Prealps. This complex occurs near the base of the Prealpine nappe stack, between a complex zone comprising tectonic mélanges and Ultrahelvetic slices below and the Préalpes Médianes nappe above (Figs. 1,2), and consists of vertically stacked flysch successions generally forming a large synform with numerous internal folds (Weidmann et al. 1976; Morel 1980; Winkler 1983; Ospina-Ostios 2017). In this paper, we are only concerned with the Gurnigel and the Voirons Flyschs (Fig. 2a, b, respectively). The former encompasses a succession of five units (Flyschs 1-5; Fig. 3a), discriminated by subtle differences in lithology, that have been dated from the Maastrichtian to the Middle Eocene by calcareous nannofossil biostratigraphy (Fig. 3a, 4; Weidmann et al. 1976; Morel 1980). The latter includes four formations (from base to top, Fig. 3b): the Voirons Sandstone, the Vouan Conglomerate, the Boëge Marl, and the Bruant Sandstone formations (Ragusa, 2015). Originally attributed to a time interval from the Danian to the Priabonian (nannofossil zones NP 2 to NP18; Fig. 5) based on coccolith and dinoflagellate assemblages (Jan du Chêne et al. 1975; Van Stuijvenberg 1980; Van Stuijvenberg and Jan du Chêne 1980), this flysch succession has more recently been dated to the Middle Eocene-Early Oligocene (Figs. 3b, 5; planktonic foraminiferal zones P13 to P20) based on planktonic foraminifera (Ujetz 1996; Coppo 1999; Frébourg 2006; Ospina-Ostios et al. 2013; OspinaOstios 2017). No nannofossils younger than the Priabonian has ever been found in these lithologies.

The selected outcrops are found in the southern part of the Gurnigel Flysch (Figs. 1, 2). Located to the SE of Châtel-St-Denis, in the Veveyse de Fégire gorges, the first section exposes the lower to middle Eocene Flysch 3 (Fig. 3a; Weidmann et al. 1976). The second outcrop is in the Veveyse de Châtel valley, to the $\mathrm{N}$ of Les Paccots, and comprises lithologies attributed to the middle Eocene Flysch 4 (Fig. 3a; Morel 1980). The revised samples from the Voirons massif have been borrowed from the collections of Lina Ospina-Ostios and Grégory Frébourg (samples LMO and GF, respectively), both of which are deposited at the Department of Earth Sciences of the University of Geneva. These samples represent all stratigraphic units from the Voirons Flysch, except for the Bruant Sandstone Fm (Fig. 2). GPS coordinates and stratigraphic attribution of these samples are given in Table 1.

The Schlieren Flysch (Winkler 1983, 1984) comprises a lithostratigraphic succession similar to that of the Gurnigel Flysch. Nannofossil biostratigraphy gave a Late Maastrichtian to late Ypresian age to this flysch (Late Maastrichtian to nannofossil zone NP14; Winkler 1984; Caron et al. 1989; Fig. 6). The Wägital Flysch (Winkler et al.

\section{(a) Gurnigel Flysch}

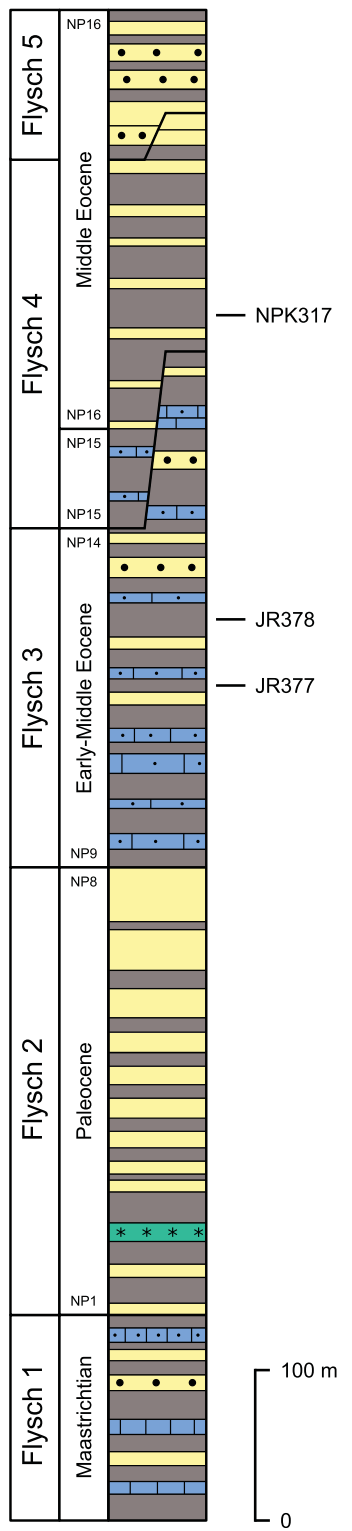

(b) Voirons Flysch

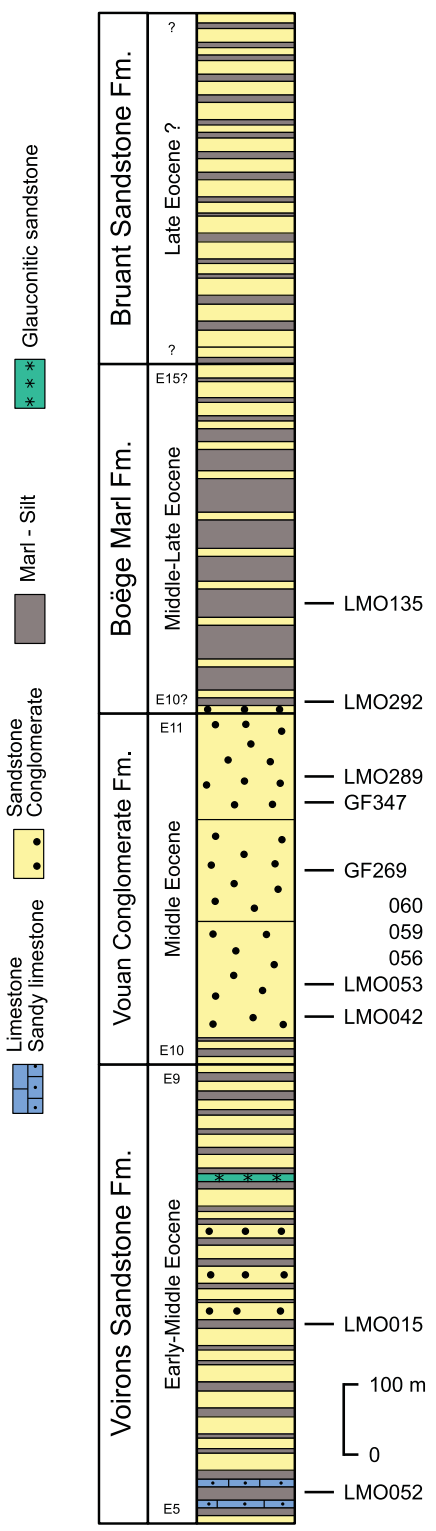

Fig. 3 Synthetic stratigraphic logs from the Gurnigel Flysch (Weidmann et al. 1976, modified) and Voirons Flysch with the position of the studied samples

$1985)$ is roughly subdivided into three units, and extends from the Campanian to the Middle Eocene (Fig. 6).

\section{Methods}

In turbidites, the upper portions of thick shale beds have the highest probability to represent pelagic deposits (Mutti et al. 2003; Mulder and Alexander 2001). We thus looked for such layers in the selected exposures from the Gurnigel Flysch, and gathered ca. $500 \mathrm{~g}$ of material at depth with a 


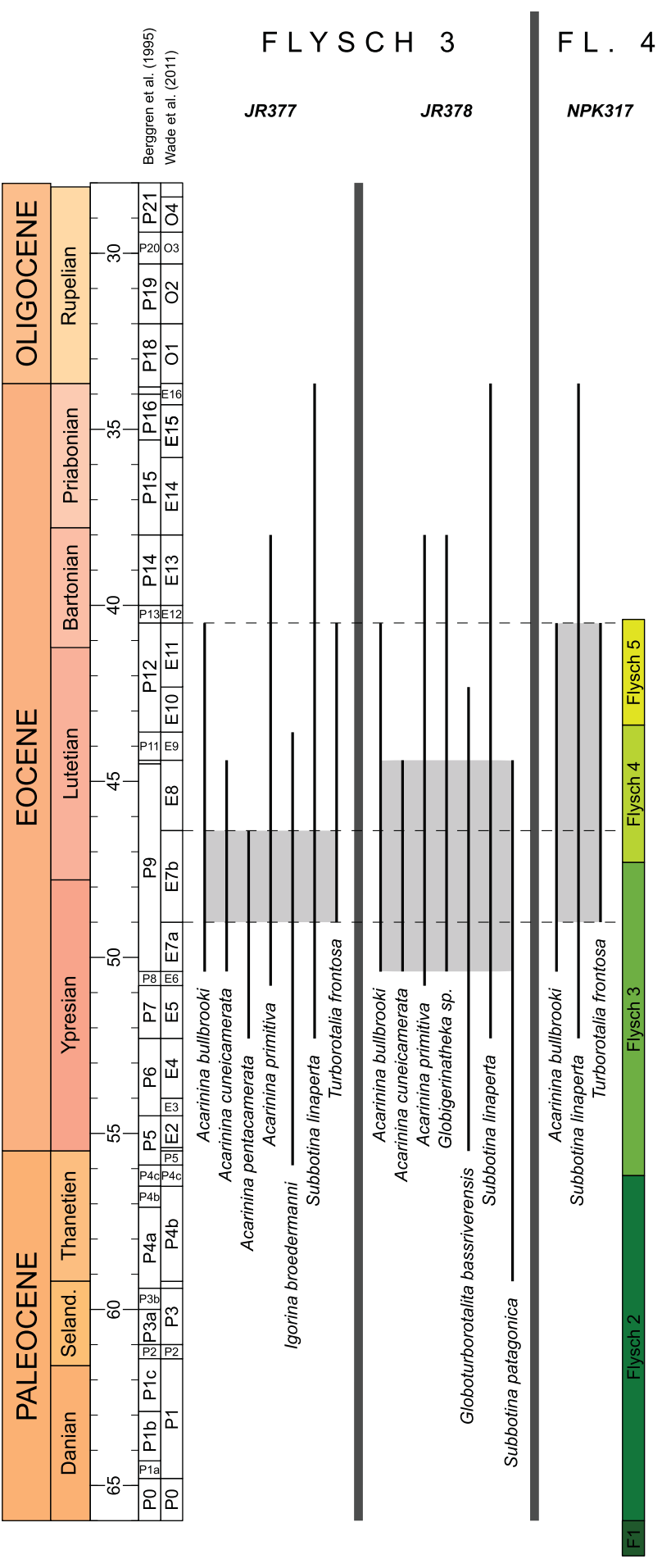

Fig. 4 Age ranges of the Gurnigel Flysch based on nannofossil biostratigraphy (Weidmann et al. 1976; Morel 1980), and age ranges of the studied and revised samples based on planktonic foraminifera biostratigraphy. Dark grey shades correspond to the age range of samples

clean spatula to avoid field contamination. Samples were then disaggregated with gasoline, washed, and wet-sieved through $90-1000 \mu \mathrm{m}$ sieves for qualitative planktonic foraminiferal analyses. For the Voirons Flysch, we simply used the leftover residues of samples collected by previous researchers (Frébourg 2006; Ospina-Ostios 2017). After manual picking, selected specimens were photographed with a Nikon digital camera mounted on a Nikon SMZ18 stereomicroscope fitted with a $0.5 \times$ SHR Plan Apo objective. Images were taken of each specimen using the NIS Elements Imaging Software v4.60. Finally, the foraminifera illustrated in the plates published by OspinaOstios et al. (2013) and Ospina-Ostios (2017) were re-examined and, in some cases, re-determined. Species determinations and age ranges are based on Pearson et al. (2006) and Wade et al. (2011). The P Zones of Berggren et al. (1995) are also used in the text to facilitate comparison with previous works. The comparison with $\mathrm{E}$ and $\mathrm{P}$ Zones are reported in Figs. 4, 5 and 6. Nannofossil biostratigraphy is based on Martini (1971) (Fig. 6).

\section{Results}

\subsection{Gurnigel Flysch}

The exposure in the Veveyse de Fégire gorges (Figs. 2, 7a; GPS coordinates in Table 1) consists of well-exposed, shale-dominated, distal turbidites (F8-F9; Mutti et al. 2003) characterized by the Tb-Te intervals of the Bouma sequence. The thickness of sandstone beds seldom exceeds $10 \mathrm{~cm}$, whereas that of intercalated shales varies between $50 \mathrm{~cm}$ and $1 \mathrm{~m}$. Strata occur in normal position, and dip sharply $\left(60^{\circ}\right)$ towards the East. These turbidites were originally correlated with the Early to Middle Eocene (nannofossil zones NP 12 to NP 15; Weidmann et al. 1976). Samples JR 377 and JR 378 (Fig. 3a) were collected from pelagic marls identified by their greenish colour that contrasts with the dark-grey tint of the Te intervals (Fig. 7b). The assemblage of poorly preserved planktonic foraminifera retrieved from these samples contains acarinids (Online Resource 1), and suggests also an Early to Middle Eocene age (planktonic foraminiferal zones E7b or P9) for this exposure.

The Veveyse de Châtel outcrop (Figs. 2, 7c; GPS coordinates in Table 1) likewise shows distal turbidites (F8-F9; Mutti et al. 2003) with dm-scale, bioturbated, shaly intervals and thin $(5-20 \mathrm{~cm})$ laminated sandstone beds (Tb-Td). This succession is in normal position and displays a low dip $\left(30^{\circ}\right)$ towards the SE (Fig. 7c). A few pebbly sandstone beds (F2; Mutti et al., 2003) occur near the top of the exposure. These deposits were previously attributed to the Middle Eocene (nannofossil zones NP 15 to NP 16; Weidmann et al. 1976; Morel 1980). Sample NPK 317 was collected from grey marls located just below a $5 \mathrm{~cm}$-thick sandstone bed (Fig. 7d). The assemblage of 


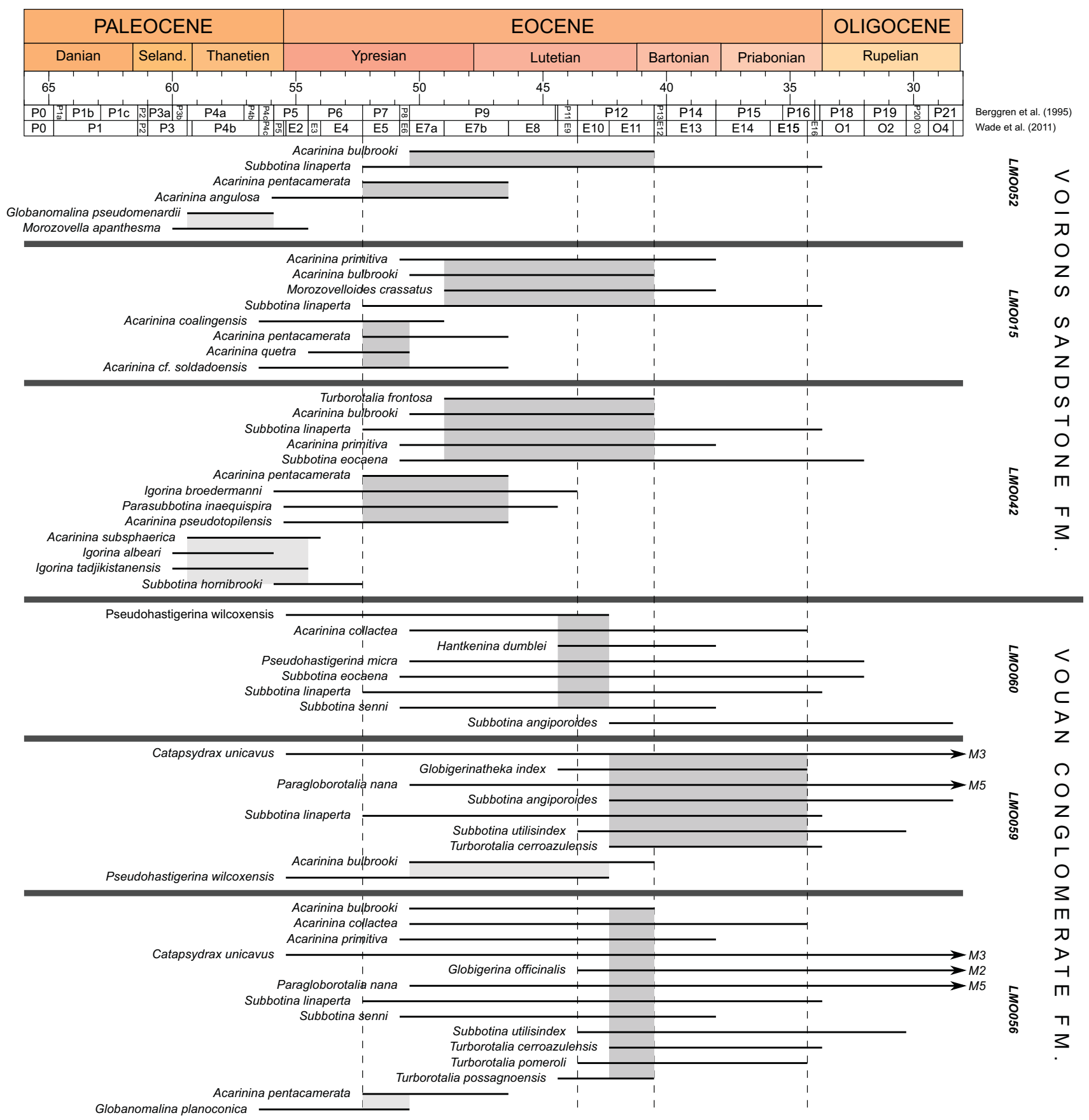

Fig. 5 Age ranges of the studied and revised samples of the Voirons Flysch based on planktonic foraminifera biostratigraphy. Dark grey shades correspond to the age range of samples and light grey shades for reworking

poorly preserved planktonic foraminifera found in this sample (Online Resource 1 and 2) gave an age ranging from the late Early Eocene to the late Middle Eocene (planktonic foraminiferal zones E7b to E11, or P9 to P12).

\subsection{Voirons Flysch}

The residues of five samples regularly distributed within the sandstone-dominated Voirons Sandstone Fm. were re- picked and re-examined. Their geographic and stratigraphic positions are given in Figs. 2, $3 \mathrm{~b}$ and Table 1. Previous studies based on nannofossils (Jan du Chêne et al. 1975; Van Stuijvenberg 1980) and planktonic foraminifera (Ospina-Ostios et al. 2013; Ospina-Ostios 2017) placed this formation in the Paleocene to Middle Eocene (nannofossil zones NP2 to NP16) and in the Middle Eocene to Early Oligocene (planktonic foraminiferal zones P13 to P19), respectively. The planktonic foraminiferal assemblages, 


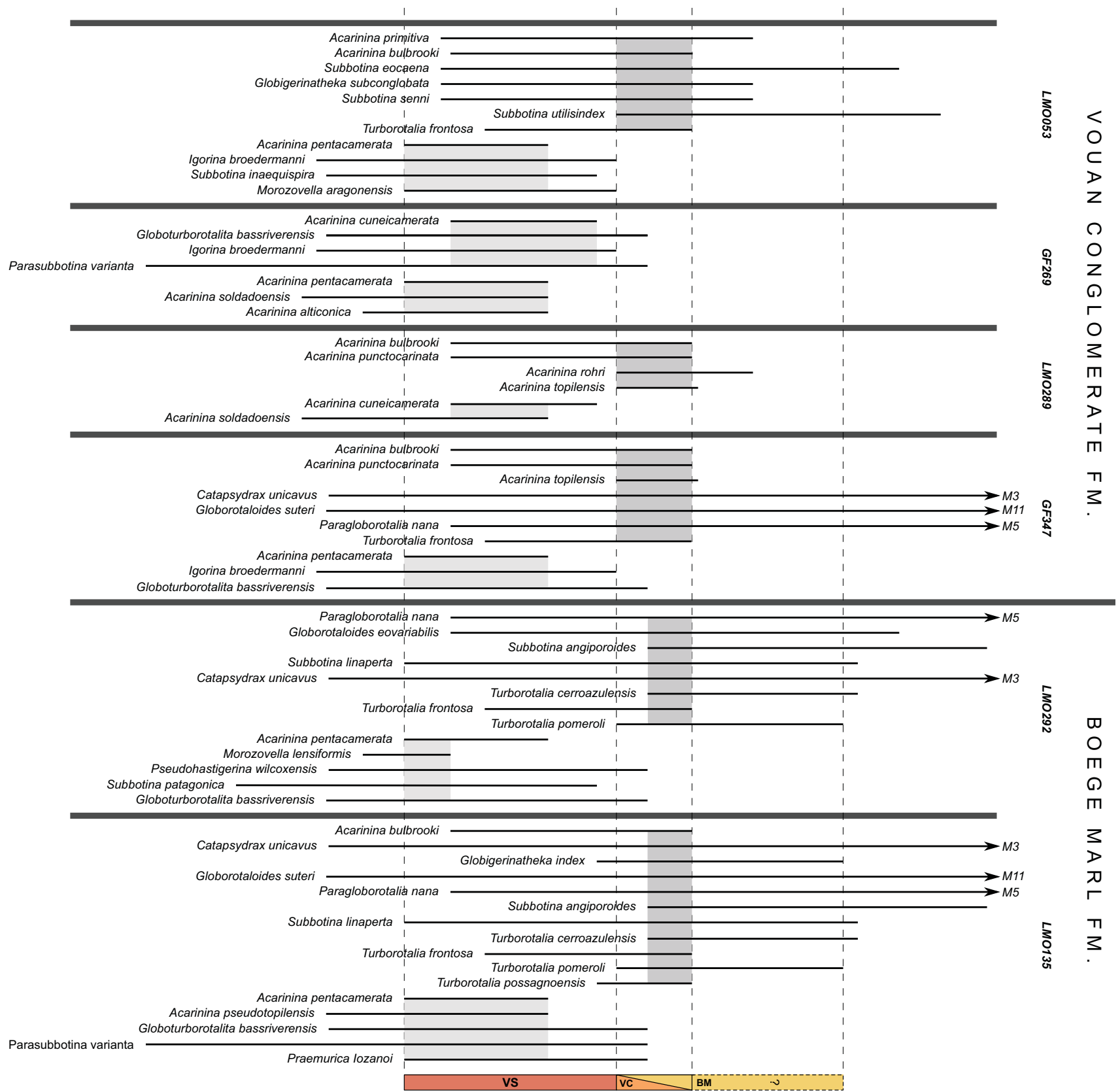

Fig. 5 continued

some of them well-preserved (e.g. sample LMO042), are presented in Online Resource 1. Collectively, these revised data constrain the age of the Voirons Sandstone Fm. between the Early and the Middle Eocene (planktonic foraminiferal zones E5-E9, or P7-P11). Reworked specimens of Cretaceous and Paleocene age have also been observed in these assemblages.

Likewise, the residues of four samples gathered from rare shaly intervals or mud pebbles (e.g. sample GF 269) scattered in the coarse-grained Vouan Conglomerate Fm. were reconsidered. The geographic and stratigraphic position of the outcrops from which they were collected are given in Figs. 2, 3b and Table 1, respectively. Previous studies based on nannofossils (Jan du Chêne et al. 1975; Van Stuijvenberg 1980) and planktonic foraminifera (Frébourg 2006; Ospina-Ostios et al. 2013; Ospina-Ostios 2017) placed this formation in the Middle Eocene (nannofossil zones NP 15 to NP16) and in the late Middle Eocene to Early Oligocene (planktonic foraminiferal zones P15-P19), respectively. The planktonic foraminiferal assemblages are shown in Online Resource 1, and selected specimens are illustrated in Online Resource 2 and 3. The 


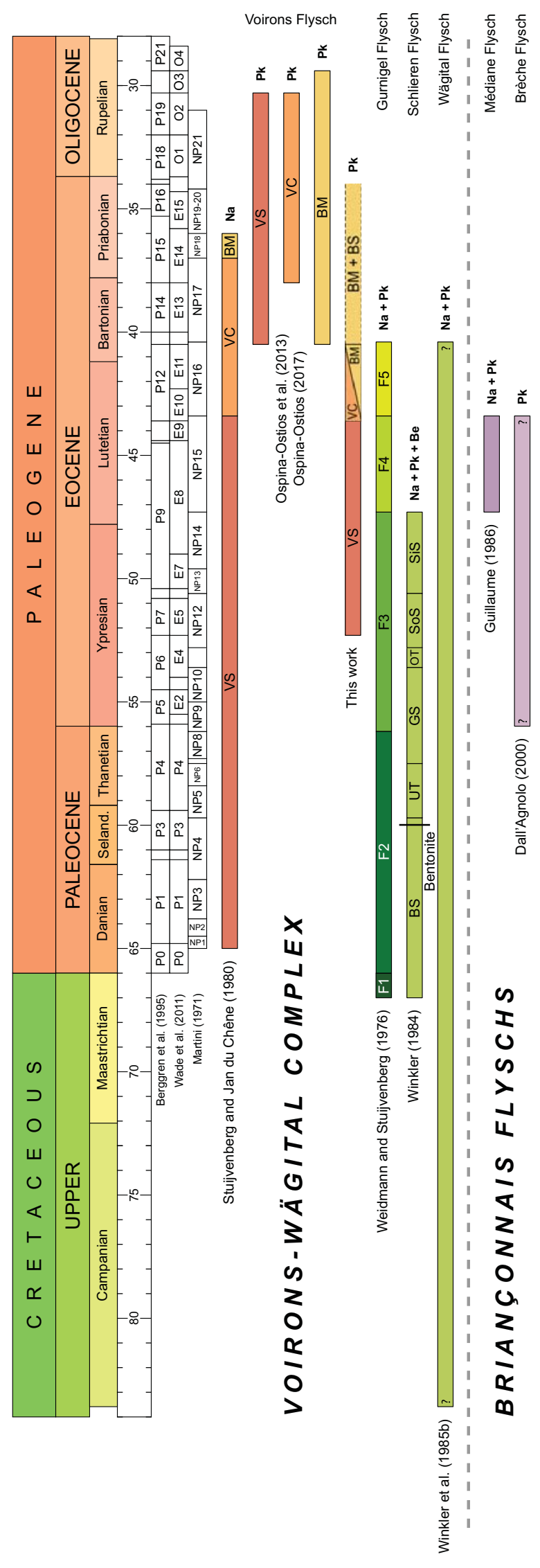

4Fig. 6 Comparison of the successive age ranges of the Voirons Flysch with the other flyschs of the Voirons-Wägital complex and the Briançonnais flyschs. Bentonite age from Koch et al. (2015). Be large benthic foraminifera, $\mathrm{Na}$ calcareous nannofossils, $P k$ planktonic foraminifera

assemblages from all four samples contain numerous reworked forms, and yield up to three ages in the Eocene. Sample LMO056 gave the most recent and precise age in the Middle Eocene (planktonic foraminiferal zone E11 or P12), which overlaps the Lutetian-Bartonian boundary.

Only two samples from the lower part of the shaledominated Boëge Marl Fm. were re-evaluated. Section from upper layers are barren of planktonic specimens (Dranse outcrop; Jan du Chêne et al. 1975). Their geographic and stratigraphic positions are in Figs. 2, 3b and Table 1. The planktonic foraminiferal assemblages are listed in Online Resource 1, and selected specimens are illustrated in Online Resource 2 and 3. Previous studies based on nannofossils (Van Stuijvenberg and Jan du Chêne 1980) and planktonic foraminifera (Coppo 1999; OspinaOstios et al. 2013; Ospina-Ostios 2017) placed this formation in the Late Eocene (nannofossil zones NP18) and in the late Middle Eocene to Early Oligocene (planktonic foraminiferal zones P13 to P20), respectively. Like the material retrieved from the Vouan Conglomerate Fm., the planktonic foraminiferal assemblages identified in these two samples contain numerous reworked Early to Middle Eocene and even Cretaceous forms (e.g. hedbergellids in LMO292). The youngest age obtained for both samples is Middle Eocene (planktonic foraminiferal zones E11 or P12). It is identical to that obtained from the underlying Vouan Conglomerate Fm. Due to the paucity of shaly layers, no samples were collected from the sandstonedominated, highly tectonised Bruant Sandstone Fm.

Thus, according to our new and revised data, the age of the Voirons fFlysch ranges from the Early Eocene to the late Middle Eocene, i.e. from the Late Ypresian to the Early Bartonian (planktonic foraminiferal zones P7-P12). No specimen of planktonic foraminifera with a range restricted to the Late Eocene or Early Oligocene age was detected in the studied residues.

\section{Discussion}

\subsection{Comparison with previous biostratigraphic results}

The foraminiferal ages acquired from the two samples collected from the Gurnigel Flysch agree with the previous biostratigraphic data based on nannofossils (Weidmann et al. 1976; Morel 1980). By contrast, our new data do not 

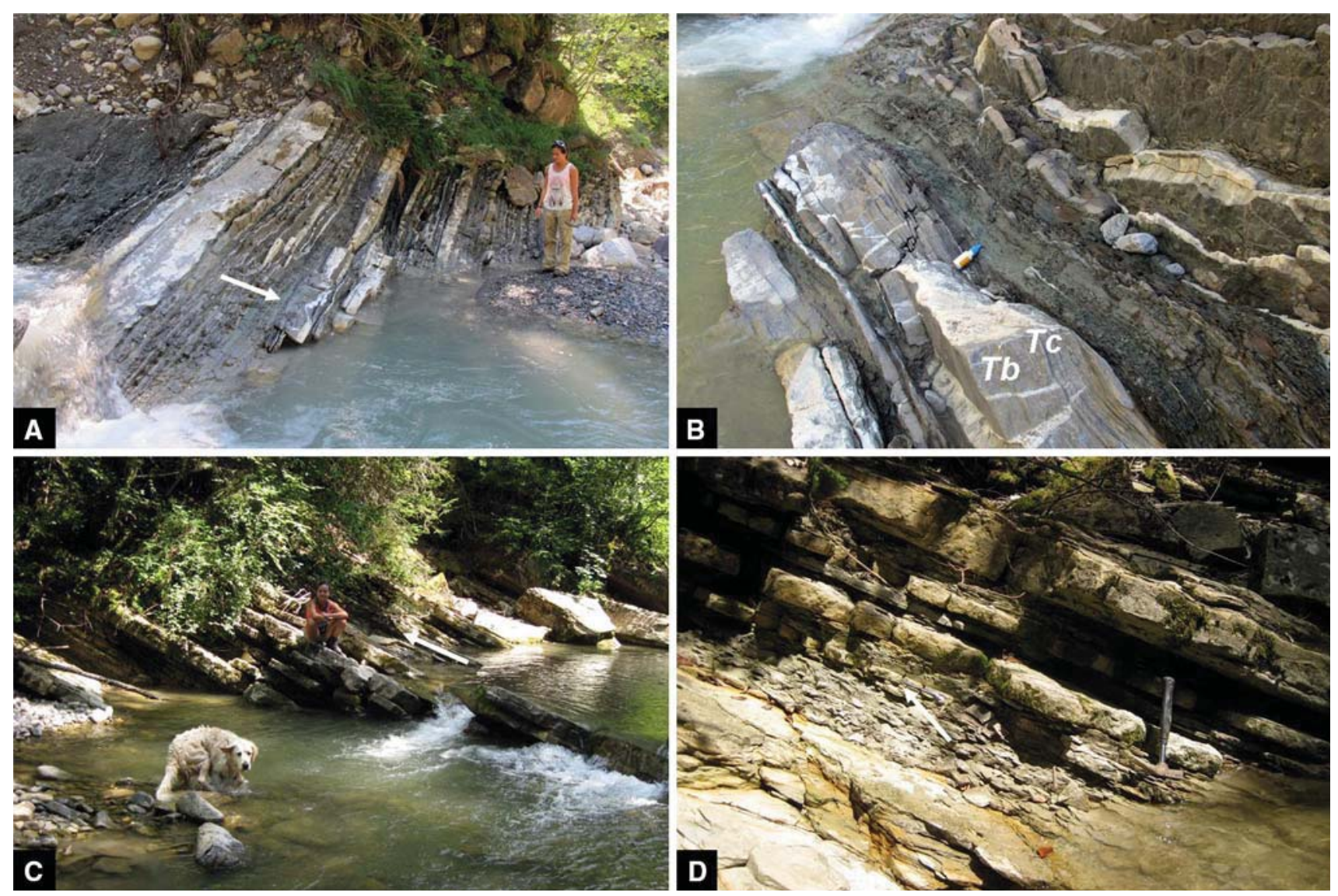

Fig. 7 Studied exposures in the Gurnigel Flysch. a Partial view of the Veveyse de Feygire exposure. Arrow indicates where samples JR 377 and 378 were collected. Person for scale is $1.58 \mathrm{~m}$ tall. b Same location. Close-up on sampling spot. Note color difference between pelagic marls (greenish) and Te interval (grey). Bottle for scale is

fully agree with any biostratigraphic result previously found in the Voirons Flysch. The older ages obtained from nannofossil analyses (Jan du Chêne et al. 1975; Van Stuijvenberg and Jan du Chêne 1980) for the onset of flysch sedimentation (Danian or Thanetian versus Ypresian) can be explained by considering that the Paleocene forms observed by these authors have been reworked (see Sect. 5.2). Similarly, the slight offset between the nannofossil age (Early Priabonian; Van Stuijvenberg and Jan du Chêne 1980) and our data (Early Bartonian) for the end of flysch deposition could likely be related to the small number of revisited samples from the Boëge Marl Fm. However, the important discrepancies between our study and those of Ospina-Ostios et al. (2013) and Ospina-Ostios (2017), all of which relying on planktonic foraminifera biostratigraphy, cannot be easily dismissed, and are further discussed below.

$3 \mathrm{~cm}$ long. $\mathbf{c}$ Partial view of the Veveyse de Châtel exposure. Arrow indicates where sample PK 317 was collected. Dog (for scale) is approximately $1 \mathrm{~m}$ long from head to tail base. d Closer view of sampling spot (arrow)

\subsection{Discrepancies in planktonic foraminifera biostratigraphy}

The expansion of the Ocean Drilling Program (ODP) in the 80 's and more recently of the Integrated Ocean Drilling and International Discovery Programs (IODP) have added a huge amount of information about planktonic foraminiferal ranges and taxonomy with the recovery of continuous sedimentary sequences and very well-preserved planktonic foraminiferal species. The pioneering comprehensive work of Toumarkine and Luterbacher (1985) on Palaeogene planktonic foraminifera has been revised and completed in the Atlases of Paleocene and Eocene Planktonic Foraminifera compiled by the Palaeogene Planktonic Foraminifera Working Groups (PPFGW) active since 1987 (Olsson et al. 1999; Pearson et al. 2006). These comprehensive monographies not only present a new biologically guided classification of planktonic foraminifera based on the characteristics of the wall textures, but also refined 
Table 1 Geographical location and age ranges of the studied samples

\begin{tabular}{|c|c|c|c|c|c|c|}
\hline Sample & Geological unit & Site & $\begin{array}{l}\text { Location } \\
\text { Fig. } 2\end{array}$ & $\begin{array}{l}\text { Geographic } \\
\text { coordinates (WGS84) }\end{array}$ & $\begin{array}{l}\text { Age ranges } \\
\text { (Wade et al. 2011) }\end{array}$ & Remarks \\
\hline \multicolumn{7}{|c|}{ Voirons Flysch } \\
\hline LMO052 & Voirons Sandstone Fm. & Bons quarry & A & $\begin{array}{l}\text { E6.391322- } \\
\text { N46.255011 }\end{array}$ & E5-E7b, E7a-E11, P4 & \\
\hline LMO015 & Voirons Sandstone Fm. & Monastery road & B & E6.358315-N46.22799 & E5-E6, E7b-E11 & Late Cretaceous forms \\
\hline LMO042 & Voirons Sandstone Fm. & Morand bridge & $\mathrm{C}$ & $\begin{array}{l}\text { E6.371186- } \\
\text { N46.164862 }\end{array}$ & $\begin{array}{l}\text { P4-P5, E5-E7, E7b- } \\
\text { E11 }\end{array}$ & Late Cretaceous forms \\
\hline LMO060 & $\begin{array}{l}\text { Vouan Conglomerate } \\
\text { Fm. }\end{array}$ & Saxel upper quarry & $\mathrm{D}$ & $\begin{array}{l}\text { E6.396003- } \\
\text { N46.252292 }\end{array}$ & E9-E10 & \\
\hline LMO059 & $\begin{array}{l}\text { Vouan Conglomerate } \\
\text { Fm. }\end{array}$ & Saxel upper quarry & $\mathrm{D}$ & $\begin{array}{l}\text { E6.396003- } \\
\text { N46.252292 }\end{array}$ & E7-E10, E11-E15 & \\
\hline LMO056 & $\begin{array}{l}\text { Vouan Conglomerate } \\
\text { Fm. }\end{array}$ & Saxel upper quarry & $\mathrm{D}$ & $\begin{array}{l}\text { E6.396003- } \\
\text { N46.252292 }\end{array}$ & E5, E11 & \\
\hline LMO053 & $\begin{array}{l}\text { Vouan Conglomerate } \\
\text { Fm. }\end{array}$ & Saxel upper quarry & $\mathrm{D}$ & $\begin{array}{l}\text { E6.396003- } \\
\text { N46.252292 }\end{array}$ & E5-E7, E10-E11 & \\
\hline GF269 & $\begin{array}{l}\text { Vouan Conglomerate } \\
\text { Fm. }\end{array}$ & Molière grind quarry & $\mathrm{E}$ & $\begin{array}{l}\text { E6.370147- } \\
\text { N46.187306 }\end{array}$ & E5-E7, E7-E8 & Entirely reworked \\
\hline LMO289 & $\begin{array}{l}\text { Vouan Conglomerate } \\
\text { Fm. }\end{array}$ & Vachat grind quarry & $\mathrm{F}$ & $\begin{array}{l}\text { E6.376809- } \\
\text { N46.175282 }\end{array}$ & E5-E7, E10-E11 & \\
\hline GF347 & $\begin{array}{l}\text { Vouan Conglomerate } \\
\text { Fm. }\end{array}$ & Vachat grind quarry & $\mathrm{F}$ & $\begin{array}{l}\text { E6.376809- } \\
\text { N46.175282 }\end{array}$ & E7b, E10-E11 & \\
\hline LMO292 & Boëge Marl Fm. & $\begin{array}{l}\text { Chauffemérande } \\
\text { stream }\end{array}$ & G & $\begin{array}{l}\text { E6.389323- } \\
\text { N46.169689 }\end{array}$ & E5-E6, E11 & $\begin{array}{l}\text { (Late) Cretaceous } \\
\text { forms }\end{array}$ \\
\hline LMO135 & Boëge Marl Fm. & Supersaxel road & $\mathrm{H}$ & $\begin{array}{l}\text { E6.403001- } \\
\text { N46.243125 }\end{array}$ & E5-E7, E11 & \\
\hline \multicolumn{7}{|c|}{ Gurnigel Flysch } \\
\hline JR377 & Flysch 3 & Veveyse de Fégire & I & $\begin{array}{l}\text { E6.932667- } \\
\text { N46.503267 }\end{array}$ & $\mathrm{E} 7 \mathrm{~b}$ & \\
\hline JR378 & Flysch 3 & Veveyse de Fégire & I & $\begin{array}{l}\text { E6.932667- } \\
\text { N46.503267 }\end{array}$ & E7a-E8 & \\
\hline NPK317 & Flysch 4 & Veveyse de Châtel & $\mathrm{J}$ & $\begin{array}{l}\text { E6.944167- } \\
\text { N46.526667 }\end{array}$ & E7b-E11 & \\
\hline
\end{tabular}

ranges for each species at a global scale. The advantage of these atlases is that holotypes and, in some cases, also paratypes of each species are imaged, mostly with the environmental SEM, and we have now the documentation of type specimens that, in most cases, were only illustrated by drawings.

Ospina-Ostios et al. (2013) and Ospina-Ostios (2017) mostly used the taxonomy and species ranges reported in Toumarkine and Luterbacher (1985) and the time scale of Luterbacher et al. (2004). The more recent biostratigraphy and taxonomic works of Pearson et al. (2006) and Wade et al. (2011) have been only used to update generic names. Additionally, they have not used the classification of planktonic foraminifera based on wall texture. Although the planktonic foraminifera from the Gurnigel Flysch are very poorly preserved, it is still possible to identify the details of the wall texture for most specimens. One example is the specimen illustrated on Online Resource 3 (6b) of Ospina-Ostios et al. (2013) identified as Tenuitellinata angustiumbilicata. This form shows a coarsely cancellate wall texture typical of macroperforate genera (e.g. Paragloborotalia or Subbotina) instead of the microperforate wall texture typical of the genus Tenuitellinata. The main discrepancies between the studies of Ospina-Ostios et al. (2013) and Ospina-Ostios (2017) and the present work are generally due to the different approaches in classification of species and the use of different zonal schemes.

Thus, based on our revision of previous data, the onset of sedimentation of the Voirons Flysch spans the interval zones P7-P9 (as in Berggren et al. 1995) corresponding to Zones E5-E7 of Wade et al. (2011), whereas the end of deposition can be mostly restricted to zone P12 (as in Berggren et al. 1995) corresponding to zones E10-E11 (Wade et al. 2011). However, we cannot rule out that sedimentation continued as late as the Priabonian (Figs. 5, 6) because we only revised two samples from the lower part of the Boëge Marl Fm. and none from the overlying Bruant Sandstone Fm. Such an attribution would agree with previously obtained results based on nannofossil biostratigraphy that suggested an early Priabonian maximum age (nannofossil zone NP 18) for the Boëge Marl Fm. 
(Jan du Chêne et al. 1975; Van Stuijvenberg and Jan du Chêne 1980).

\subsection{Reworking in the Voirons Flysch}

The comparison of biostratigraphic ranges allows to reconstruct some sedimentary processes throughout the Voirons Flysch. Samples of the Voirons Sandstone Fm. include reworked specimens of Late Paleocene age (Fig. 5). Such an age is not reported in the Voirons Flysch, and may be derived either from (1) extrabasinal marly successions or (2) an older upstream equivalent of the Voirons Sandstone Fm. The latter hypothesis suggests that, in contrast to the other flyschs from the Voirons-Wägital complex (Fig. 6), Paleocene sediments might have been tectonically removed during an early phase of thrusting. Similarly, the presence of Upper Cretaceous specimens (Campanian to Maastrichtian) may involve a contribution from basinal marls of Mesozoic age.

The Vouan Conglomerate Fm. consistently comprises specimens reworked from the Voirons Sandstone Fm. However, these elements are missing in the sample LMO060 collected from the lower part of this unit, indicating that reworking processes started after a short delay. This break can also be observed in the field where the basal part of the Vouan Conglomerate Fm. corresponds to a sandstone-marl alternation (Saxel upper quarry; Ragusa 2015). In addition, the restricted range of sample GF269 (Fig. 5) suggests that the mud pebbles occurring within some beds of the Vouan Conglomerate Fm. may directly derive from the Voirons Sandstone Fm.

The biostratigraphic range of the Boëge Marl Fm. does not differ from that of the Vouan Conglomerate Fm (Fig. 5), and also comprises reworked specimens from the Voirons Sandstone Fm. We suppose that the youngest age obtained from the Boëge Marl Fm. reflects reworking from the Vouan Conglomerate Fm. This marly succession corresponds to a starvation period, enabling the destabilisation of the turbiditic system. Hence, the obtained Lutetian-early Bartonian age may emphasize the remobilisation of upstream components of the Vouan Conglomerate Fm. basinward, corroborating the occurrence of one single conglomeratic bed at the base of the Boëge Marl Fm (Ragusa 2015; Ospina-Ostios 2017). The presence of late Ypresian to Lutetian foraminifera also confirms a contribution from the Voirons Sandstone Fm. Finally, the occurrence of Upper Cretaceous specimens, that are missing in the Vouan Conglomerate Fm., also suggests that this unit originates from the same source as the Voirons Sandstone Fm., as previously confirmed by the similar detrital composition (Ragusa et al. 2017). Consequently, sampling in the upper part of the unit, where detrital sedimentation rate increases, may better constrain the depositional age of the Boëge Marl Fm. which probably ends during Priabonian (planktonic foraminiferal zones E15-P16) from calcareous nannofossil biostratigraphy.

\subsection{Comparison with the other flyschs of the Voirons-Wägital complex and palaeogeographic implications}

As the age of the Voirons Flysch is now constrained between the Ypresian and the Priabonian, the whole Voirons-Wägital complex ranges from the Campanian to the Late Eocene (Fig. 6), which corresponds to a ca. 49.7 Ma-long interval. The accumulation time of the Voirons Flysch (ca. $18 \mathrm{Ma}$ ) is shorter than that of the Gurnigel (ca. 26.6 Ma; Weidmann et al. 1976; Morel 1980) and Schlieren Flyschs (ca. 19.7 Ma; Winkler 1983, 1984), whereas sedimentation of the Wägital Flysch lasted for about 45.6 Ma (Winkler et al. 1985), spanning the time interval of the complex. The age ranges of the different flyschs become younger towards the West, suggesting a scissor-like closure of the basin (Winkler 1984). Sedimentation started during the Late Cretaceous in the eastern units, but only initiated during the Early Eocene in the Voirons Flysch. Similarly, sedimentation ended in the Early Eocene in the Wägital Flysch, and probably stopped in the Late Eocene in the Voirons Flysch.

Although our revised age of the Voirons Flysch is similar to that previously obtained from nannofossil biostratigraphy (Fig. 6; Jan du Chêne et al. 1975; Van Stuijvenberg and Jan du Chêne 1980), it does not necessarily re-establish a South Penninic origin for this unit, and for that matter for the whole Voirons-Wägital complex. These flyschs needed accommodation space before, during and after the deposition of the Briançonnais flyschs, especially of the Médiane Flysch (Fig. 6; Guillaume 1986), which substantiates a palaeogeographic location in the Valais domain. Thus, our revised biostratigraphic data on the Voirons Flysch requires an update of the palaeogeographic model proposed by Ragusa et al. (2017), which will be detailed in a publication currently in preparation.

\section{Conclusion}

The ages derived from the examination of planktonic foraminiferal assemblages from the Gurnigel Flysch and from our revision of material gathered by previous researchers from the Voirons Flysch reveal only minor discrepancies with earlier studies based on nannofossil biostratigraphy (Jan du Chêne et al. 1975; Weidmann et al. 1976; Morel 1980; Van Stuijvenberg and Jan du Chêne 1980; Van Stuijvenberg 1980). By contrast, there are major divergences between the results of our work and those of 
previous studies on the Voirons Flysch similarly based on planktonic foraminifera (Ujetz 1996; Coppo 1999; Frébourg 2006; Ospina-Ostios et al. 2013; Ospina-Ostios 2017). These discrepancies are generally related to the different approaches in species classification and the use of different zonal schemes. Based on our revised data, the age of the Voirons Flysch extends from the Early Eocene (planktonic foraminiferal zone E5 or P7) to the Middle Eocene (planktonic foraminiferal zone E11 or P12). Contrary to claims made in the aforementioned studies, specimens restricted to Late Eocene or Early Oligocene age have not been observed in the samples and in the illustrations we re-examined. However, we cannot exclude a younger age (possibly early Late Eocene) for the upper reaches of this flysch from which we did not have samples to re-examine. Further sampling in the upper part of the Boëge Marl Fm. and Bruant Sandstone Fm. will be investigate to better constrain the age from the top of the flysch deposition. Thus, additional research and sampling are needed to resolve this question. Finally, the palaeogeographic origin of the Voirons-Wägital complex as well as the sedimentation history of these flyschs need now to be re-evaluated in light of this revised biostratigraphic data.

Acknowledgements $\mathrm{We}$ are grateful to the constructive review and remarks of the Chief Editor and critical reviews by Ursula Menkveld.

\section{References}

Berggren, W. A., Kent, D. V., Swisher, C. C., \& Aubry, M.-P. (1995) A revised Cenozoic geochronology and chronostratigraphy. In W. A. Berggren, D. V. Kent, M.-P. Aubry, \& J. Hardenbol (Eds.), Geochronology, time scales and global stratigraphic correlations (Vol. 54, pp. 129-212). Tulsa: SEPM Special Publication. https://doi.org/10.7916/d8xd1b1h.

Bouma, A. (1962). Sedimentology of some Flysch deposits: A graphic approach to facies interpretation. Amsterdam: Elsevier.

Caron, C. (1976). La nappe du Gurnigel dans les Préalpes. Eclogae Geologicae Helvetiae, 69, 297-308. https://doi.org/10.5169/ seals- 164510 .

Caron, C., Homewood, P., Morel, R., \& Van Stuijvenberg, J. (1980). Témoins de la Nappe du Gurnigel sur les Préalpes médianes: une confirmation de son origine ultrabriançonnaise. Bulletin de la Société fribourgeoise des Sciences naturelles, 69, 64-79. https:// doi.org/10.5169/seals-308586.

Caron, C., Homewood, P., \& Wildi, W. (1989). The original Swiss flysch: a reappraisal of the type deposits in the Swiss Prealps. Earth-Science Reviews, 26, 1-45. https://doi.org/10.1016/00128252(89)90002-0.

Cogulu, E. (1961). La géologie des Voirons et de la colline des Allinges. Master dissertation, University of Geneva, Geneva, Switzerland.

Coppo, N. (1999). Géologie de la région Voirons-Vouan. Master dissertation, University of Geneva, Geneva, Switzerland.

Dall'Agnolo, S. (2000). Le Crétacé de la Nappe de la Brèche (Préalpes franco-suisses): données nouvelles et essai de synthèse stratigraphique et paléogéographique. Eclogae Geologicae Helvetiae, 93, 157-174. https://doi.org/10.5169/seals-168814.
Frébourg, G. (2006). Les Conglomérats du Vouan: un cañon turbiditique? Master dissertation, University of Geneva, Geneva, Switzerland.

Gasinski, A., Slaczka, A., \& Winkler, W. (1997). Tectono-sedimentary evolution of the Upper Prealpine nappe (Switzerland and France): nappe formation by Late Cretaceous-Paleogene accretion. Geodinamica Acta, 10, 137-157. https://doi.org/10.1080/ 09853111.1997.11105299.

Guillaume, M. (1986). Revision stratigraphique des Couches Rouges de la nappe des Préalpes médianes romandes. Ph.D. dissertation, University of Fribourg, Fribourg, Switzerland.

Handy, M. R., Schmid, S. M., Bousquet, R., Kissling, E., \& Bernoulli, D. (2010). Reconciling plate-tectonic reconstructions of Alpine Tethys with the geological-geophysical record of spreading and subduction in the Alps. Earth-Science Reviews, 3-4, 121-158. https://doi.org/10.1016/j.earscirev.2010.06.002.

Heckel, H. (1968). Möglichkeiten einer stratigraphischen Gliederung des Gurnigel-Flyschs auf Grund von Nannofossilzonen. Eclogae Geologicae Helvetiae, 61, 500-504. https://doi.org/10.5169/ seals-163598.

Homewood, P., \& Caron, C. (1982). Flysch of the Western Alps. In K. J. Hsü (Ed.), Mountain building processes (pp. 157-168). London: Academic Press.

Homewood, P., \& Lateltin, O. (1988). Classic swiss clastics (flysch and molasse) The alpine connection. Geodinamica Acta, 2, 1-11. https://doi.org/10.1080/09853111.1988.11105150.

Hsü, J. K., \& Schlanger, S. O. (1971). Ultrahelvetic Flysch sedimentation and deformation related to plate tectonics. Geological Society of America Bulletin, 82, 1207-1217. https://doi. org/10.1130/0016-7606(1971)82[1207:UFSADR]2.0.CO;2.

Jan du Chêne, R., Gorin, G., \& Van Stuijvenberg, J. (1975). Étude géologique et stratigraphique (palynologie et nannoflore calcaire) des Grès des Voirons (Paléogène de Haute-Savoie. Géologie Alpine, 51, 51-78.

Koch, S., Winkler, W., Von Quadt, A., \& Ulmer, P. (2015). Paleocene and Early Eocene volcanic ash layers in the Schlieren Flysch, Switzerland: U-Pb dating and Hf-isotopes of zircons, pumice geochemistry and origin. Lithos, 236-237, 324-337. https://doi. org/10.1016/j.lithos.2015.07.008.

Kuenen, P. H., \& Carozzi, A. V. (1953). Turbidity currents and sliding in geosynclinal basins of the alps. The Journal of Geology, 61, 363-373. https://doi.org/10.1086/626101.

Lombard, A. (1940). Géologie des Voirons. Mémoire de la Société helvétique des Sciences Naturelles.

Luterbacher, H. P., Ali, J. R., Brinkhuis, H., Gradstein, F. M., Hooker, J. J., Monechi, S., et al. (2004). The Paleogene period. In F. G. Gradstein, J. G. Ogg, \& A. G. Smith (Eds.), A geologic time scale 2004 (pp. 384-408). Cambridge: Cambridge University Press. https://doi.org/10.1017/cbo9780511536045.021.

Martini, E. (1971). Standard Tertiary and Quaternary calcareous nannoplankton zonation. In A. Farinacci (Ed.), Proceedings of the 2nd Planktonic Conference, Roma 1970 (pp. 739-785). Roma.

Matter, A., Homewood, P., Caron, C., Rigassi, D., Van Stuijvenberg, J., Weidmann, M., Winkler, W. (1980). Flysch and Molasse of Western and Central Switzerland. In R. Trümpy (Ed.), Geology of Switzerland, a Guide Book (pp. 261-293). Schweizerische geologische Kommission.

Menkveld-Gfeller, U., Kempf, O., \& Funk, H. (2016). Lithostratigraphic units of the Helvetic Palaeogene: review, new definition, new classification. Swiss Journal of Geosciences, 109, 171-199. https://doi.org/10.1007/s00015-016-0217-4.

Morel, R. (1980). Géologie du massif du Niremont (Préalpes romandes) et de ses abords. Bulletin de la Société fribourgeoise des Sciences naturelles, 69, 99-207. https://doi.org/10.5169/ seals-308588. 
Mulder, T., \& Alexander, J. (2001). The physical character of subaqueous sedimentary density flows and their deposits. Sedimentology, 48, 269-299. https://doi.org/10.1046/j.13653091.2001.00360.x.

Mutti, E., Bernoulli, D., Ricci-Lucchi, F., \& Tinterri, R. (2009). Turbidites and turbidity currents from Alpine 'flysch' to the exploration of continental margins. Sedimentology, 56, 267-318. https://doi.org/10.1111/j.1365-3091.2008.01019.x.

Mutti, E., Tinterri, R., Benevelli, G., Biase, D., \& Cavanna, G. (2003). Deltaic, mixed and turbidite sedimentation of ancient foreland basins. Marine and Petroleum Geology, 20, 733-755. https://doi. org/10.1016/j.marpetgeo.2003.09.001.

Olsson, R. K., Hemleben, C., Berggren, W. A., \& Huber, B. T. (1999). Atlas of Paleocene planktonic foraminifera. Smithsonian contributions to paleobiology. Washington: Smithsonian Institution Press. https://doi.org/10.5479/si.00810266.85.1.

Ospina-Ostios, L.M. (2017). Biostratigraphy and structure of the Voirons Flysch (Gurnigel Nappe, Haute-Savoie, France). Ph.D. dissertation, University of Geneva, Geneva, Switzerland.

Ospina-Ostios, L. M., Ragusa, J., Wernli, R., \& Kindler, P. (2013). Planktonic foraminifer biostratigraphy as a tool in constraining the timing of flysch deposition: Gurnigel flysch, Voirons massif (Haute-Savoie, France). Sedimentology, 60, 225-238. https://doi. org/10.1111/sed.12013.

Pearson, P. N., Olsson, R. K., Huber, B. T., Hemeleben, C., \& Berggren, W. A. (2006). Atlas of eocene planktonic foraminifera (p. 44). Philadelphia: Cushman Foundation Special Publication.

Pilloud, J. (1936). Contribution à l'étude stratigraphique des Voirons. Préalpes externes, Haute-Savoie. Archives des Sciences de la Société de Physique et d'Histoire naturelle de Genève, 18, 219-249.

Ragusa, J. (2015). Pétrographie, stratigraphie et provenance du Flysch des Voirons (Nappe du Gurnigel, Haute-Savoie, France). Ph.D. dissertation, University of Geneva, Geneva, Switzerland.

Ragusa, J., Kindler, P., Segvic, B., \& Ospina-Ostios, L. M. (2017). Provenance analysis of the Voirons Flysch (Gurnigel nappe, Haute-Savoie, France): stratigraphic and palaeogeographic implications. International Journal of Earth Sciences, 106, 2619-2651. https://doi.org/10.1007/s00531-017-1474-9.

Rigassi, D. (1958). Foraminifères des "Grès des Voirons". Archives des Sciences, 11, 398-400.

Schaub, H. (1951). Stratigraphie und Paläontologie des Schlierenflysches mit besonderer Berücksichtigung der pa- leocaenen und untereocaenen Nummuliten und Assilinen. Abhandlungen der Schweizerischen Paläontologischen Gesellschaft, 68, 1-217.

Schaub, H., Hay, W. W., \& Mohler, H. P. (1965). Schlierenflysch. Bulletin der Vereinigung Schweiz. Petroleum-Geologen und Ingenieure, 31, 124-134. https://doi.org/10.5169/seals-193347.

Scheibner, C., \& Speijer, R. P. (2008). Late Paleocene-early Eocene Tethyan carbonate platform evolution-a response to long- and short-term paleoclimatic change. Earth Science Reviews, 90, 71-102. https://doi.org/10.1016/j.earscirev.2008.07.002.

Schmid, S. M., Fügenschuh, B., Kissling, E., \& Schuster, R. (2005). Tectonic map and overall architecture of the Alpine orogen. Eclogae Geologicae Helvetiae, 98, 99-101. https://doi.org/10. 1007/s00015-004-1113-x.
Stampfli, G. M., Borel, G. D., Marchant, R., \& Mosar, J. (2002). Western Alps geological constraints on western Tethyan reconstructions. Journal of the Virtual Explorer, 7, 75-104. https:// doi.org/10.3809/jvirtex.2002.00057.

Stampfli, G. M., \& Hochard, C. (2009). Plate tectonics of the Alpine realm. Geological Society, London, Special Publications, 327, 89-111. https://doi.org/10.1144/SP327.6.

Studer, B. (1848). Sur la véritable signification du nom de Flysch. Actes de la Société Helvétique des Sciences Naturelles, 33, 32-35.

SwissTopo. (2008). Tektonische Karte der Schweiz 1:500 000 Geologische Bearbeitung durch: Institut für Geologie, Universität Bern, und Bundesamt für Wasser und Geologie. ISBN 3-906723-56-9.

Toumarkine, M., \& Luterbacher, H. (1985). Paleocene and Eocene planktic foraminifera. In H. Bolli (Ed.), Plankton stratigraphy (pp. 87-154). Cambridge: Cambridge University Press.

Trümpy, R. (1960). Paleotectonic evolution of the central and western Alps. Geological Society of America Bulletin, 71, 843-908. https://doi.org/10.1130/0016-7606(1960)71[843:PEOTCA]2.0. $\mathrm{CO} ; 2$.

Trümpy, R. (2006). Geologie der Iberger Klippen und ihrer FlyschUnterlage. Eclogae Geologicae Helvetiae, 99, 79-121. https:// doi.org/10.5169/seals-169227.

Ujetz, B. (1996) Micropaleontology of Paleogene deep water sediments, Haute-Savoie, France. Ph.D. dissertation, University of Geneva, Geneva, Switzerland.

Van Stuijvenberg, J. (1980). Stratigraphie et structure de la Nappe du Gurnigel aux Voirons, Haute-Savoie. Bulletin de la Société fribourgeoise des Sciences naturelles, 69, 80-96. https://doi.org/ $10.5169 /$ seals-308587.

Van Stuijvenberg, J., \& Jan du Chêne, R. (1980). Nouvelles observations stratigraphiques dans le massif des Voirons. Bulletin du BRGM, 1, 3-9.

Wade, B. S., Pearson, P. N., Berggren, W. A., \& Pälike, H. (2011). Review and revision of Cenozoic tropical planktonic foraminiferal biostratigraphy and calibration to the geomagnetic polarity and astronomical time scale. Earth-Science Reviews, 104, 111-142. https://doi.org/10.1016/j.earscirev.2010.09.003.

Weidmann, M., Morel, R., \& Van Stuijvenberg, J. (1976). La nappe du Gurnigel entre la Baye de Clarens et la Veveyse de Châtel. Bulletin de la Société fribourgeoise des Sciences naturelles, 65, 182-196. https://doi.org/10.5169/seals-308540.

Wildi, W. (1987). Les régions sources du matériel terrigène dans les flyschs alpins. Géologie Alpine, Mémoire Hors-Série, 13, 379-388.

Winkler, W. (1983). Stratigraphie, Sedimentologie und Sedimentpetrographie des Schlieren-Flysches (Zentralschweiz). Matériaux pour la Carte Géologique Suisse, 158.

Winkler, W. (1984). Palaeocurrents and petrography of the GurnigelSchlieren flysch: A basin analysis. Sedimentary Geology, 40, 169-189. https://doi.org/10.1016/0037-0738(84)90045-9.

Winkler, W., Wildi, W., Van Stuijvenberg, J., \& Caron, C. (1985). Wägital-Flysch et autres flyschs pennique en Suisse Centrale. Stratigraphie, sédimentologie et comparaisons. Eclogae Geologicae Helvetiae, 78, 1-22. https://doi.org/10.5169/seals-165641. 